\title{
Inequalities in the workforce distribution in the Brazilian Dentistry
}

\author{
Desigualdades na distribuição da força de trabalho na Odontologia brasileira
}

\author{
Marilisa Carneiro Leão GABARDO ${ }^{1}$ \\ Rafael Gomes DITTERICH² \\ Marcia Regina CUBAS $^{3}$ \\ Simone Tetu MOYSÉS 4 \\ Samuel Jorge MOYSÉS ${ }^{4}$
}

\begin{abstract}
This article aimed to describe the distribution of dental professionals in Brazil, through a narrative review. The approach is based on the assumptions which lead the individual in choosing such career and as well as their fragmented current practices due to the university educational curriculum process. Furthermore, data are revised on the geographical distribution of these individuals and the potential impacts, among others, in the epidemiological profile of the population oral health problems. It was evident that the workforce shifts as presented in different ways in society and influenced by social needs, public policy and market, play special roles. It discusses the urgency of socio-spatial redistribution of dentists, a role to be played collaboratively among different States in Brazil, regulatory and social control agencies. Finally, the role of dental courses in forming active subjects was highlighted, in the process of health improvement, aiming to build a more equitable and just society.
\end{abstract}

Indexing terms: Dentistry. Mouth diseases. Workforce.

\section{RESUMO}

O presente artigo teve por objetivo descrever a distribuição dos profissionais da área odontológica no Brasil, por meio de uma revisão narrativa. A abordagem parte dos pressupostos que levam o indivíduo a optar por essa carreira e passa à observação das práticas atuais fragmentadas em virtude do processo de formação universitária. Ainda, são revistos dados relativos à distribuição geográfica destes indivíduos e os possíveis impactos, dentre outros, no perfil epidemiológico de problemas bucais da população do país. Evidenciou-se que a força de trabalho se desloca/ fixa de formas diferentes na sociedade e sofre influência das necessidades sociais, das políticas públicas e do mercado. Discute-se a premência da redistribuição socioespacial dos cirurgiões-dentistas, papel a ser desempenhado de modo colaborativo entre Estado, órgãos fiscalizadores e instâncias de controle social. Por fim, destacou-se a função dos cursos de Odontologia em formar sujeitos atuantes no processo de melhorias no setor da saúde, com vistas a uma sociedade mais equânime e justa.

Termos de indexação: Odontologia. Doenças da boca. Força de trabalho.

\section{INTRODUCTION}

The professional career choice is often made at a stage of life in which the young person can be influenced by the image of some professional of reference, by family pressure or even by the ideal of an activity which presents a certain social prestige. In the case of the choice by Dentistry it would be convenient to observe, in this preliminary problem, which professional inheritance will be updated by each dentist who chooses this career.

The surge of Dentistry as a modern profession, of higher-level, occurred in consonance with the social and economic scenario, marked by the industrialization process, as well as by the epidemiological magnitude represented by dental caries increase ${ }^{1}$. In this context, a model of "odontocentric" professional practice has emerged, meaning to a focus on procedures aimed at painless procedures regarding dental origin and filling, or extraction of the compromised tooth. Despite such knowledge and practices/technologies available and acceptable in the past, it is astonishing that such practices remain in the current days of university education, still leading the subject-apprentice to follow traditional models, focused on liberal practice, restricted and curative based in fragmented and specialized

\footnotetext{
${ }^{1}$ Pontifícia Universidade Católica do Paraná, Departamento de Odontologia. Rua Imaculada Conceição, 1155, Prado Velho, 80215901, Curitiba, PR, Brasil. Correspondência para / Correspondence to: MCL GABARDO. E-mail: <marilisa.gabardo@pucpr.br>.

2 Universidade Federal do Paraná, Departamento de Saúde Comunitária. Curitiba, PR, Brasil.

3 Pontifícia Universidade Católica do Paraná, Programa de Pós-Graduação em Tecnologia em Saúde. Curitiba, PR, Brasil.

${ }^{4}$ Pontifícia Universidade Católica do Paraná, Programa de Pós-Graduação em Odontologia. Curitiba, PR, Brasil.
} 
knowledge, even often mutilating ones. However, the National Curricular Guidelines for Dentistry undergraduate courses came precisely to boost the transformation process in the opposite direction to the model ${ }^{2}$. Thus, professionals with a general professional vision coming from Dentistry school disciplines and sociobiological factors which determine oral diseases as well as health promotion, these dental professional would be better suited to future trends, human and ethical aspects ${ }^{2-3}$.

In addition to this, the present narrative review aimed to describe the distribution of dental professionals in Brazil.

\section{Dental professionals at present in Brazil}

Brazil has been seeking to upgrade strategies in order to improve the oral health conditions, particularly proposed by government programs. As a consequence, pro-active professionals in the field of primary care, can have a promising career.

However, due to Brazil's development situation and the structuring of the health sector, which is still far from desirable, the country is characterized by inequalities both concerning diseases ${ }^{4}$ and the distribution of health professionals in its territory ${ }^{4-5}$.

In the dental area, specifically, the private market has shown greater number of professionals enrolled in the Regional Council of Dentistry of the State of São Paulo, associated with better social indicators such as the Gini Index, the Condition of Life Index and the average per capita family income ${ }^{6}$. The same authors have stated that the principle of equity in public service has been followed, insofar as human and material resources are in accordance with the needs of the population.

It is observed that Brazil presents quantitative and qualitative imbalance in relation to oral health professionals, with marked consequences for the provision of services, either public or private. Quantitatively the country experiences a scenario of great disproportion concerning professional/inhabitants rate by regions ${ }^{5}$. In the qualitative aspect, university education does not offer adequate formation regarding the private market and the public sector needs ${ }^{7-9}$. According to the ideologies imposed by the higher education process itself, where private practice is stimulated, secondary employment is characterized by low paid though stable jobs ${ }^{10}$. Thus, the professionals working under the National Unified Health System (Sistema Único de Saúde - SUS) do not present the qualification profile, with actions based on evidence, training and commitment to health equity ${ }^{10}$. Efforts have been made in order to change this perspective. The Program for the Reorientation of Vocational Training in Health (Programa de Reorientação da Formação Profissional em Saúde - Pró-Saúde) ${ }^{11}$ and the Program for Education through Work for Health (Programa de Educação pelo Trabalho para a Saúde - PET-Saúde) $)^{12}$ are projects which could be examples which encourage multiprofessional experience, the use of technologies, in addition to the teaching-servicecommunity integration. Thus, the students are given the opportunity to approach the practices supported by SUS ${ }^{13-}$ 14.

The SUS is nowadays the great workforce employer, and its growing association with the public service, both partially or integrally, has been relevant in Dentistry ${ }^{5}$. The inclusion of oral health actions in the Family Health Strategy, through Ordinance No. 1444, of December 28, $2000^{15}$, triggered dental care expansion through SUS ${ }^{16}$. Nonetheless, the public sector is not able to satisfactorily absorb the large number of professionals seeking for the stability offered by the system. Public contests have revealed that, in addition to newly trained professionals in search of the first job, there are those who have been in the market for years, however due to the current profession difficulties, they also dispute job opportunity in public services ${ }^{17}$.

These facts meet other studies which have questioned the role of the government in organizing the professions according to the role of university education ${ }^{9}$. Universities end up giving in to decisions based on the private world, determined by the laws of the market ${ }^{18}$ due to economic and speculative pressure concerning the process of education and professional training together with the training apparatus expansion in dental area as part of the medical field ${ }^{18}$. Almeida-Filho ${ }^{10}$ points out three facts which favor this situation: a) the immature young person, coming from expensive preparatory courses generally to enter undergraduate courses, such as Medicine, receives the imposition in career decision, is then part of an elitist higher education, based on individualistic values and actions; b) there is few incentive to promote a broad and humanistic view of diseases and health care; and c) curricula which focus on specialty, not interdisciplinary values.

This context reinforces the need for professionally training individuals who are able of critically understand their role within society, with a view to promote the population health improvement, supported health services enhancement, along with perceiving the changes introduced in the health sector and by overcoming the 
medical hegemony posture in the health approach, so that the new professionals get involved in the search for justice and social equity ${ }^{18}$.

The Brazilian government, motivated by the concern to minimize the barriers generated by the marked inequalities in oral health, has launched proposals with this objective, as in the case of the Smiling Brazil Program, $2004^{19}$. Its objectives were to increase the number of oral health teams composed by dentists, auxiliaries and hygienists, and the acquisition of dental offices which resulted in coverage increase ${ }^{19}$.

Another aspect to be pointed out in this discussion refers to the increasing number of Dentistry courses in Brazil. In 1991, there were 83 presential courses; in 2004 this number rose to 174 , representing an increase of $109.64 \%{ }^{17}$. In 2009, the Federal Council of Dentistry (Conselho Federal de Odontologia - CFO) registered 191 colleges in the country ${ }^{20}$. The greatest concentration of openings for new courses and new vacancies occurred in the Southeast and South regions, followed by the Northeast ${ }^{17}$. Current data have shown that both public and private education courses are mostly concentrated in the Southeast region

It is wise to observe the responsibility that the universities have in the presented context. The opening of Dentistry courses is a debatable and worrying topic in Brazil since the promulgation, in 1961, of the Law on the Guidelines and Bases of National Education, established financial and legal support for the private unviersities ${ }^{17}$. In order to understand the size of the Brazilian disproportion, a country like the United States of America (USA) in the years 2008/2009 had 57 Dentistry schools21, where the organization policy performs a certain "control" in the education, and what can be called "import" or "export" of professionals according to local needs. A survey of 35,000 dental professionals evaluated how this process really takes place in the USA, a process in which a number of conditions may determine whether graduates remain in the State where the course was completed. This analysis is essential for coping with labor-power problems in the country, characterized by irregular professional distribution ${ }^{22}$. In Australia, Canada and in European countries the highest concentration of professionals also occurs in urban areas ${ }^{23-25}$.

At the same time, Brazil faces a serious problem regarding the establishment of the professional and concentration of courses in certain regions, which could be remedied through organizational strategies in order to maintain professionals in the socially and economically disadvantaged regions, as well as a containment policy to open new courses in more developed regions.

Population aging is also an essential fact concerning changes related to the profession. Accumulated diseases, such as periodontal alterations as well as the teeth absence can impair the clinical condition that will be prevalent in the future. These facts do not occur exclusively in Brazil, as reported in other studies ${ }^{26-27}$. The European Union, for example, has for a long time been suffering from a decline in caries disease in the 12-year old group, in addition to the clear population aging. These facts change oral diseases scenario where the focus was on caries increase. Professionals have sought different alternatives to overcome the market crisis should be emphasized. Health care plans that include Dentistry cooperatives, insurance companies, so-called "Dentistry group", among others, have been increasing. These modalities tend to continue on the market as they become attractive to the client who considers them less expensive and in many cases even health benefit offered by many companies to their employees. All these facts add up and become highly profitable for the entrepreneurs of this branch ${ }^{28-29}$.

In $1998,42.3 \%$ of the Dentistry course graduates stated that they intended to look for a stable job, instead of their own private dental clinics. This rate increased to $70.7 \%$ in 2003 , revealing that the search for more stable jobs has been increasing ${ }^{17}$.

The last decade showed that $47.6 \%$ of the 614 professionals interviewed in a 2003 survey, developed by the CFO together with the Brazilian Institute of SocioEconomic Studies and Research, stated having had more profitably while working in dental cooperatives. The statement accounted for $14.7 \%$ of respondents ${ }^{30}$.

While discussing the labor market in Dentistry, it is necessary to point out possible private and public sector peculiarities. The private sector can be influenced by the patient's direct search for services both by financial situation and by educational and behavioral factors, such as the fear of the dental treatment. On the other hand, the public sector would be subject to the governmental organization, which follows a hierarchy of priorities, job functions, wages and adjustments according to the epidemiological scenario and the population needs. One of the greatest problems faced by this sector is due to the instability of the supply-service-demand ratio.

The issues mentioned above are in line with those highlighted by the CFO survey ${ }^{30}$. The major problems faced by dental surgeons working in the private/liberal sector are: material costs $(40.8 \%)$, payment of fees $(30.3 \%)$, social 
level of patients (28.4\%), and treatment prices (24.7\%). In the public sector the main problems are related to wages $(53.4 \%)$ and working conditions $(36.0 \%)^{30}$.

Regarding the dental market in several neo-liberal countries, it can be observed a professional concentration in large urban centers, contrary to the popular mass without dental treatment access $22-25,31$, similar to Brazil. Personal characteristics and lifestyle choice ${ }^{32}$, added to geographical characteristics of the chosen place, family issues, leisure, earnings and job opportunities ${ }^{25,33}$ are factors which influence the choice for services in a given locality ${ }^{25,33}$.

This irregularity of professional distribution was highlighted by the CFO survey ${ }^{30}$. The Southeast region accounted for $60.6 \%$ of the respondents, followed by the South and Northeast regions, with $14.5 \%$ and $12.4 \%$, respectively. The urban area retained $96.9 \%$ of dentists. Another data showed that $89.6 \%$ of the professionals were self-employed, compared to $26.2 \%$ under public service, however $47.7 \%$ of the individuals would like to participate in some internalization program ${ }^{30}$.

Current research showed a significant concentration of professionals in the South and Southeast regions, with the State of São Paulo comprising 33.08\% of the total number of dentists in Brazil' ${ }^{5}$. However, a new and relevant data of this same research was the internal migration of dentists to population growth areas mainly on the North and Central-West regions. The Brazilian States that stood out for job transfer enrollment were Acre, Roraima and Amapá. The Federal District was also sought because of the greater concentration of public jobs and the high local per capita income ${ }^{5}$.

Unequal and markedly self-employed professional distribution is influenced by social and economic factors, with repercussions on the inadequate organization of services, whether in the public or private scenario. In this context, besides the professionals it is the user of the dental care who is in disadvantage, since he is often in a condition where he can not afford the treatment, but also can not access the public service network.

As for the provision of dental services, public policies aimed at increasing access are fundamental to overcome the stigma that Dentistry is a practice aimed at few, marked by social exclusion.

Professional disbelief in the government's performance in relation to health policies aimed at Dentistry was reported by $59.9 \%$ of respondents ${ }^{30}$. What role does the State play in this process, that is what kind of working conditions does the government offer for dental workers? First of all, the state government must be able to promote the regulation of labor relations and the practice of professions, considered as "critical nodes" for adequate sector management and for the protection of the consumers ${ }^{34}$. From there, the principles of efficiency and equity in health services can be reached.

It is important to clarify that there is no preestablished definition as to the proportion of ideal number of dentists according to the number of inhabitants. The World Health Organization states that this distribution varies according to socioeconomic, cultural and epidemiological factors ${ }^{32}$.

Some studies illustrate the different forms of professional distribution and performance in the country ${ }^{17,35-37}$. Regarding the spatial distribution, the highest concentration of professionals is in the following order: Southeast, Center-West, South, Northeast and North, a pattern that follows the distribution of per capita income in the country ${ }^{17}$ and is reinforced by the Survey of Medical-Sanitary Assistance of $2005^{37}$, which highlighted the professional concentration in the Southeast and South regions, followed by the Center-West of the country for any type of public or private health establishment. These distribution data corroborate with other findings, where the Southeast and South regions have emerged ${ }^{5}$.

Regarding the type of care provided, which characterizes the type of service, the 1998 National Household Sample Survey (Pesquisa Nacional de Amostra por Domicilios - PNAD) revealed that $69 \%$ of the dental services were private, against $24 \%$ public and $17 \%$ for other healthcare plans ${ }^{35}$.

In 2003, PNAD did not show very different data ${ }^{38}$. There was a predominance for private dental care by $67 \%$ of the population, however this was not repeated when the data were global for the search of health care, whose predominance was for care through SUS ${ }^{38}$. This last point is in line with what Girardi et al. ${ }^{36}$ concluded, after analyzing national data, that from 1995 to 2000, unlike other workers, the health professions were the ones that most participated in the public sector at the same time that wages presented a considerable growth.

The public network was the one that most absorbed dentists, with emphasis on the municipalities ${ }^{37}$. In order to exemplify the professional importance in relation to the use of dental services, the increase of a professional to 1,000 inhabitants represents a $46.6 \%$ reduction in the chance that the individual will ever have a dental appointment, 
which also represents more service provision ${ }^{39}$.

Regarding the presence of the dental professional, the greater number of professionals may represent more access to the service ${ }^{40}$ and to preventive collective strategies ${ }^{41}$. Another relevant point is that routine visits to the dentist have a very positive effect on reducing dental losses $^{42}$. However, it is essential to highlight that the real impact of the professional action against oral diseases is controversial, since dental services represented only $3 \%$ of the reduction of dental caries in industrialized countries, against $65 \%$ relating to social and economic factors ${ }^{43}$. Furthermore, not even access to the dental service, where restorative treatments increased oral health improvement, still characterized by mutilating procedures ${ }^{44}$. Davenport et al. ${ }^{45}$ reported that frequent visits to the dentist are related to a greater amount of filled teeth.

The impact that dental care has on the prevalence of oral diseases shows that the reduction of inequalities in oral health is not being addressed by public services, since individuals assisted in private and union services reported better health conditions concerning tooth appearance, masticatory capacity and perceived need for treatment ${ }^{46}$.

\section{REFERENCES}

1. Pinto VG. Recursos humanos. In: Pinto VG. Saúde bucal coletiva. $5^{a}$ ed. São Paulo: Santos Editora; 2008. p. 317.

2. Brasil. Resolução CNE/CES n. 3, de 19 de fevereiro de 2002. Institui as Diretrizes Curriculares Nacionais do Curso de Graduação em Odontologia. Diário Oficial da União, Brasília (DF); 2002 mar 4 [citado 2016 Mar 10]. Disponível em: <http:// portal.mec.gov.br/cne/arquivos/pdf/CES032002.pdf>.

3. Soares EF, Reis SCGB, Freire MCM. Características ideais do cirurgião-dentista na estratégia saúde da família. Trab Educ Saúde. 2014;12(2):327-41.

4. Brasil. Ministério da Saúde, Secretaria de Atenção à Saúde, Departamento de Atenção Básica, Coordenação Nacional de Saúde Bucal. SB Brasil 2010. Pesquisa Nacional de Saúde Bucal. Resultados principais. Brasília (DF); 2012 [citado 2016 Mar 10]. Disponível em: <http://bvsms.saude.gov.br/bvs/publicacoes/ pesquisa_nacional_saude_bucal.pdf $>$.

5. Morita MC, Haddad AE, Araújo ME. Perfil atual e tendências do cirurgião-dentista brasileiro. Maringá: Dental Press; 2010.

6. Junqueira SR, Araújo ME, Antunes JLF, Narvai PC. Indicadores socioeconômicos e recursos odontológicos em Municípios do Estado de São Paulo, Brasil, no final do século XX. Epidemiol Serv Saúde. 2006;15(4):41-53. doi: 10.5123/S167949742006000400005

7. Narvai PC. Recursos humanos para a promoção da saúde bucal. In: Kriger L. Promoção de saúde bucal. São Paulo: Artes Médicas; 1997. p. 447-63.
The importance of the training process in Dentistry is emphasized, so that the subjects are aware of the health sector improvement. A socio-spatial redistribution of professionals under favorable conditions is essential so as to provide dental service establishment and maintenance, a role to be played by the State, in partnership with the supervisory fiscal bodies of the profession and social control institutions.

It was concluded that the workforce in Dentistry is distributed with inequality, under the influence of social needs, public policies and the market scene, therefore resulting in the prevalence of oral diseases.

\section{Collaborators}

MCL GABARDO collaborated in the design of the study in the article. RG DITTERICH collaborated in the writing of the article. MR CUBAS collaborated on critical review of the content. ST MOYSÉS collaborated in the bibliographic survey and in the article. SJ MOYSÉS collaborated on the study, coordination on final reading and approval of the article for submission.

8. Moysés SJ. A humanização da educação em odontologia. ProPosições/UNICAMP. 2003; 14(1): 40-74.

9. Moysés SJ. Políticas de saúde e formação de recursos humanos em Odontologia. Rev ABENO. 2004;4(1):30-7.

10. Almeida-Filho N. Higher education and health care in Brazil. Lancet. 2011. 4; 377(9781): 1898-900.

11. Brasil. Portaria interministerial n. 3.019 de 26 de novembro de 2007. Dispõe sobre o Programa Nacional de Reorientação da Formação Profissional em Saúde - Pró-Saúde - para os cursos de graduação da área da saúde. Diário Oficial da União, Brasília (DF); 2007 nov 27 [citado 2016 Mar 10]. Disponível em: $\quad<$ http://bvsms.saude.gov.br/bvs/saudelegis/gm/2007/ pri3019_26_11_2007.html>.

12. Brasil. Portaria Interministerial n. 1.802, de 26 de agosto de 2008. Institui o Programa de Educação pelo Trabalho para a Saúde. Diário Oficial da União, Brasília (DF); 2008 ago 27 [citado 2016 Mar 10]. Disponível em: <http://bvsms.saude.gov.br/bvs/ saudelegis/gm/2008/pri1802_26_08_2008.html>.

13. Mecca LE, Jitumori RT, Warkentin PF, Baldani MH, Borges PKO. Visitas domiciliares: vivenciando o emprego das diretrizes curriculares na odontologia, da teoria à pratica. Rev ABENO. 2013;13(2):62-8.

14. Silva BS, Caldarelli PG. O PET-Saúde em consonância com as Diretrizes Curriculares Nacionais de Odontologia no desenvolvimento de competências profissionais: relato de experiência. Rev ABENO. 2013;13(2):34-41.

15. Brasil. Portaria n. 1.444 de 28 de dezembro de 2000. Reorganização das ações de saúde bucal na atenção básica: 
portaria de incentivos financeiros. Diário Oficial da União, Brasília (DF); 2000 dez 29 [citado 2016 Mar 10]. Disponível em: <http://www.camara.gov.br/sileg/integras/142359.pdf>.

16. Porto SM, Santos IS, Ugá MAD. A utilização de serviços de saúde por sistema de financiamento. Cien Saude Colet. 2006;11(4):895910. doi: 10.1590/S1413-81232006000400013

17. Fernandes Neto AJ, Carvalho ACP, Kriger L, Morita MC, Toledo $O A$. Odontologia. In: Haddad AE, Pierantoni CR, Ristoff $D$, Xavier IM, Giolo J, Silva LB. (Orgs.). A trajetória dos cursos de graduação na saúde, 1991-2004. Brasília: Instituto Nacional de Estudos e Pesquisas Educacionais; 2006. p. 381-409.

18. Almeida MJ. Educação médica e saúde: possibilidades de mudança. Londrina: Editora da UEL; 1999.

19. Brasil. Ministério da Saúde, Secretaria de Atenção à Saúde, Departamento de Atenção Básica, Coordenação Nacional de Saúde Bucal. Brasil Sorridente. Brasília. [Internet]. 2004 [citado 2015 Fev 28]. Disponível em: <http://portal.saude.gov.br/portal/ saude/visualizar_texto.cfm?idtxt=21125>.

20. Conselho Federal de Odontologia. Faculdades de Odontologia existentes no Brasil: 2009 [Internet]. 2009 [citado 2015 Fev 28]. Disponível em: <http://cfo.org.br/wp-content/uploads/2009/10/ quadro_estatistico_faculdade.pdf>.

21. American Dental Association. 2008-09 Survey of dental education. Academic programs, enrollment and graduates Volume 1 Chicago: American Dental Association; 2010.

22. Lin HL, Rowland ML, Fields HW. In-state graduate retention for U.S. dental schools. J Dent Educ. 2006;70(2):1320-7.

23. Gallagher JE, Eaton KA. Health workforce governance and oral health: Diversity and challenges in Europe. Health Policy. 2015;119(12):1565-75. doi: 10.1016/j.healthpol.2015.09.010

24. Emami E, Khiyani MF, Habra CP, Chassé V, Rompré PH. Mapping the Quebec dental workforce: ranking rural oral health disparities. Rural Remote Health. 2016;16(1):3630.

25. Godwin D, Hoang H, Crocombe L. Views of Australian dental practitioners towards rural recruitment and retention: a descriptive study. BMC Oral Health. 2016;16(1):63.

26. Petersson $\mathrm{GH}$, Bratthall $\mathrm{D}$. The caries decline: a review of reviews. Eur J Oral Sci. 1996;104(4):436-43. doi: 10.1111/ j.1600-0722.1996.tb00110.x

27. Bonecker M, Cleaton-Jones P. Trends in dental caries in Latin American and Caribbean 5-6- and 11-13-year-old children: a systematic review. Community Dent Oral Epidemiol. 2003;31(2):152-7

28. Eaton KA, Widstroem EA, Renson CE. Changes in the numbers of dentists and dental caries levels in 12-year-olds in the countries of the European Union and economic area. J R Soc Health. 1998;118(1):40-8.

29. Moysés SJ. O mercado de planos odontológicos no Brasil. Rev ABO Nac. 2009;17(3):144-7.

30. Conselho Federal de Odontologia. Perfil do cirurgião-dentista no Brasil. [Internet]. 2003 [acesso 2015 fev 28]. Disponível em: <http://cfo.org.br/wp-content/uploads/2009/09/perfil_CD.pdf>.
31. Guay A. Access to dental care: solving the problem for underserved populations. J Am Dent Assoc. 2004;135(11):1599605. doi: 10.14219/jada.archive.2004.0088

32. Egger D, Lipson D, Adams O. Achieving the right balance: the role of policy-making processes in managing human resources for health problems. Evidence and information for policy. Genebra: WHO; 2000.

33. Altieri JP, Bruce SM, Crall JJ, Eklund SA, Parrish JL, Schneider DA, et al. Future of dentistry: access to future of dentistry: access to care. Today's vision: tomorrow's reality. J Am Dent Assoc. 2002;133(10):1408-24. doi: 10.14219/jada.archive.2002.0058

34. Girardi SN. Regulação dos recursos humanos em saúde e a reforma do setor saúde em países da América Latina [online]. 1999 [citado 2015 fev 28]. Disponível em: <http://www.opas. org.br/rh/admin/documentos/ACF47.pdf>

35. Barros AJD, Bertoldi AD. Inequalities in utilization and access to dental services: a nationwide assessment. Cien Saude Colet. 2002;7(4):709-17. doi: 10.1590/\$1413-81232002000400008

36. Girardi SN, Carvalho CL, Girardi Jr JB, Araújo JF. Configurações do mercado de trabalho dos assalariados em saúde no Brasil. 2004. In: Barros AFR, Santana JP, Santos Neto PM. (Orgs.). Observatório de recursos humanos em saúde no Brasil. Brasília: Ministério da Saúde; 2004. p. 121-37.

37. Instituto Brasileiro de Geografia e Estatística. Coordenação de Contas Nacionais. Estudos e Pesquisas. Informação Econômica. n. ${ }^{\circ}$ 9. Economia da Saúde: Uma perspectiva macroeconômica 2000-2005. Rio de Janeiro: IBGE; 2008 [citado 2016 Jun 28]. Disponível em: <http://www.ans.gov.br/ images/stories/Materiais_para_pesquisa/Materiais_por_assunto/ ProdEditorialOF_Economia_da_saude.pdf $>$.

38. Instituto Brasileiro de Geografia e Estatística. Diretoria de Pesquisas, Coordenação de Trabalho e Rendimento. Pesquisa Nacional por Amostra de Domicílios 2003. Rio de Janeiro: IBGE; 2003.

39. Pinheiro RS, Torres TZG. Access to oral health services between Brazilian States. Cien Saude Colet. 2006;11(4):999-1010. doi: $10.1590 / S 1413-81232006000400021$

40. Baldani $\mathrm{MH}$, Vasconcelos $\mathrm{AG}$, Antunes JL. Association of the DMFT index with socioeconomic and dental services indicators in the state of Paraná, Brazil. Cad Saude Publica. 2004;20(1):14352. doi: 10.1590/S0102-311X2004000100030

41. Fernandes LS, Peres MA. Association between primary dental care and municipal socioeconomic indicators. Rev Saude Publica. 2005;39(6):930-6. doi: 10.1590/S0034-89102005000600010

42. Cunha-Cruz J, Nadanovsky P, Faerstein E, Lopes CS. Routine dental visits are associated with tooth retention in Brazilian adults: the Pro-Saude study. J Public Health Dent. 2004; 64(4): 216-22.

43. Nadanovsky P, Sheiham A. Relative contribution of dental services to the changes in caries levels of 12-year-old children in 18 industrialized countries in the 1970s and early 1980s. Community Dent Oral Epidemiol. 1995; 23(6): 331-9.

44. Caldas Junior AF, Silveira RC, Marcenes W. The impact of restorative treatment on tooth loss prevention. Pesqui Odontol 
Bras. 2003;17(2):166-70. doi: 10.1111/j.1600-0528.1995. tb00258.x

45. Davenport C, Elley K, Salas C, Taylor-Weetman CL, Fry-Smith A, Bryan $S$, et al. The clinical effectiveness and cost-effectiveness of routine dental checks: a systematic review and economic evaluation. Health Technol Assess. 2003;7(7):1-127. doi: 10.3310/hta7070

46. Matos DL, Lima-Costa MF, Guerra HL, Marcenes W. Bambuí Project: an evaluation of private, public and unionized dental services. Rev Saude Publica. 2002;36(2):237-43. doi: 10.1590/ S0034-89102002000200017

Received on: 10/1/2016

Final version resubmitted on: 2/7/2016

Approved on: 13/7/2016 